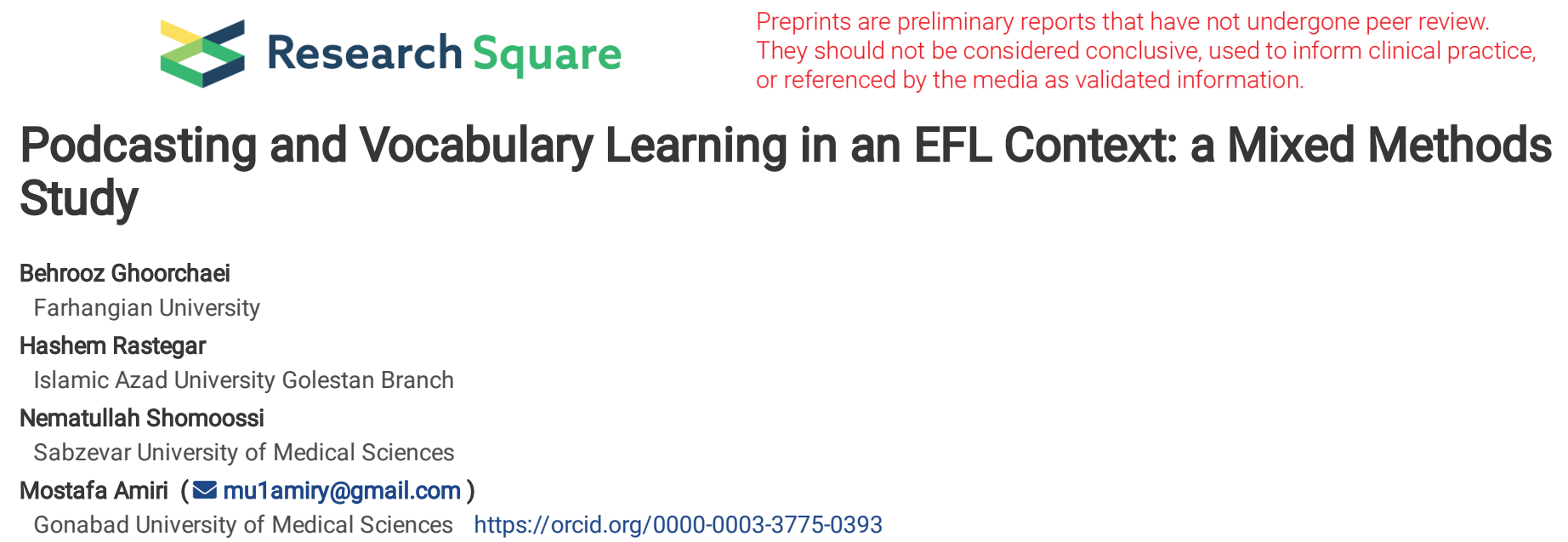

\section{Podcasting and Vocabulary Learning in an EFL Context: a Mixed Methods Study}

Behrooz Ghoorchaei

Farhangian University

Hashem Rastegar

Islamic Azad University Golestan Branch

Nematullah Shomoossi

Sabzevar University of Medical Sciences

Mostafa Amiri ( $\square$ mu1amiry@gmail.com)

Gonabad University of Medical Sciences https://orcid.org/0000-0003-3775-0393

Original article

Keywords: mobile learning, podcasting, vocabulary, EFL context

Posted Date: January 9th, 2021

DOI: https://doi.org/10.21203/rs.3.rs-141387/v1

License: () (1) This work is licensed under a Creative Commons Attribution 4.0 International License. Read Full License 


\section{Abstract}

The study investigated the impact of using podcasts as instructional tools on EFL learners' vocabulary learning, and to evaluate their attitude towards listening to podcasts. A vocabulary pre-test was given to 60 male intermediate-level EFL learners which indicated that they were homogeneous regarding their vocabulary knowledge. The participants were divided into two groups; the experimental group were instructed by podcasts, but the control group continued with the routine instruction. The results revealed that the podcast group outperformed those in the control group in the post-test. To find out the students' attitudes towards podcasting, an 8-item Likert-type questionnaire was given to the participants in the podcasting group; through face-to-face interviews with 8 participants from the same group, a thematic analysis was conducted and four themes emerged: (1) vocabulary achievement, (2) learning by listening, (3) learner choice and flexibility, and (4) podcasts as useful instructional tools. The findings suggest that podcasts enhance learners' vocabulary learning, thus emphasizing the pedagogical merits of podcasts on the enrichment of EFL classes. The results may provide implications for curriculum development and $L 2$ vocabulary teaching and learning.

\section{Introduction}

\section{The origin of podcasting}

During the past two decades, the term 'podcasting' has come to vogue on the stage of mass media, and was noted as the 'word of year 2005 ' by the New Oxford American Dictionary. Probably, Ben Hammerslay coined the term "podcasting" for the first time to denote both "iPod" and "broadcasting" (Cebeci \& Tekdal, 2006). In fact, podcasting refers to a web-based audio content delivery approach (Kim, \& King, 2011). Tending to be played on any digital audio player, podcasts are one of the newest trends in online instruction, and co-occurs with other routes of instruction such as e-learning, mobile learning, web-based learning technologies (Abdous, Camarena \& Facer, 2009). Now, they can be automatically downloaded via a subscription feed (an automatic downloading process) (Min-Tun \& Tzu-Ping, 2010). A simple web search will render a long list of podcasts with a wide range of topics for young and adult learners, for elementary or advanced learners, and so on. In these days, podcasting's popularity has enormously increased.

Historically, it is known that human beings were accustomed to listening as a primary source of learning for thousands of years. Also, as Cebeci \& Tekdal (2006) stated, learning by listening to authentic speech holds one of the most effective pedagogic advantages offered in podcasting (Golonka, Bowles , Frank, Richardson \& Freynik, 2014). Therefore, listening appears more attractive and less boring than merely reading; it can also motivate students who do not like the reading. Such unique features are appropriately integrated into 'podcasting', i.e. instruction by 'talk' rather than 'text'. ELT podcasts are particularly suggested for 'extensive listening' (Rost, 2006), where motivating students in listening activities and providing them with exposure to native speech are the focus and priority.

\section{Podcasting in language teaching}

According to students' and teachers' perception, use of 'audiovisual resources and new technologies' was one of the 19 motivational strategies Madrid (2002) explored. In this regard, podcasting as a preferable technology in computer-assisted language learning (CALL) and mobile-assisted language learning (MALL) is a promising tool, particularly for EFL contexts, where poor exposure to authentic and native communication may hamper learners from achieving higher levels of motivation and proficiency (Abdous, Camarena \& Facer, 2009).

\section{Podcasting for language learners}

Application of podcasts in learning and teaching has its own pros and cons. Some scholars are doubtful about its advantages. For example, Cann (2007), by quantitative and qualitative analyses, reported that audio podcasts were not popular with students; and even there have been doubts that podcasting might not significantly affect learning outcomes. On the contrary, other researchers considered podcasting a success. For instance, Kurtz, Fenwick and Ellsworth (2007) reported remarkable gains in students' final project grades; Evans (2008) claimed that university students were more receptive of podcast-based learning materials than to traditional lectures or textbooks; students also found podcasts to be more effective revision tools than textbooks, and considered them more efficient than personal lecture notes.

Still other scholars attribute further potential to podcasts (Asoodar, Marandi, Vaezi \& Desmet, 2016; Kim \& King, 2011; Elekaei, Tabrizi \& Chalak, 2020). According to Read (2007), podcasting brings flexibility to school and university learning; listening to recorded lectures, in particular, allows students to access and review lectures offline at convenient times; it is specifically useful for learners whose native language is not English, and need to spend more time consuming the input they receive. At certain occasions, students and teachers may cooperate in creating their own podcasts for extra-curricular purposes. Also, use of podcasts is suggested to supplement traditional textbooks by adding authentic listening materials (Kim \& King, 2011; Elekaei, Tabrizi \& Chalak, 2020). In EFL contexts, learners may also find useful communicative aspects of the language in podcast, e.g. idioms, phrasal verbs, grammatical structures, etc. (Bamanger \& Alhassan, 2015). Other advantages include one's exposure to a range of different voices, accents, social and academic. Podcast-based activities may successfully cater for two varieties of English (i.e. the formal and informal English) which is a highly neglected aspect in EFL contexts.

\section{The objectives of the study}

While there are many language learning podcasts to be found on the web, particularly for ESL users, many are for self-study and extensive listening. Currently, there are few published reports of EFL classes using and integrating this technology into their instructional materials. Therefore, the aim of the present study was to investigate the impact of using podcasts as instructional tools on Iranian EFL learners' vocabulary learning, and to evaluate their attitude towards listening to podcasts. Accordingly, the following research questions were shaped:

1. Does listening to podcasts affect the participants' vocabulary learning? 
2. What are the participants' attitudes toward using listening podcasts?

3. What are the participants' viewpoints about using listening podcasts?

\section{Methodology}

\section{Participants}

The participants of the study were 60 male intermediate EFL learners at a well-reputed Iranian language institute, i.e. Iran Language Institute (ILI), in Gonbad-e Kavus, Iran. Iran Language Institute (ILI) is a network of language institutes in most cities of Iran with predetermined syllabi for various levels of learners. The participants' level of English was not determined by proficiency tests; rather, based on ILI placement test, intermediate level learners were included in the present study. Using a vocabulary pretest, the participants were divided into two classes: class A as the experimental group ( $\mathrm{n}=30$ ), and class $\mathrm{B}$ as the control group $(n=30)$. Their bio-data were collected using a questionnaire (Appendix 1 ) at the beginning of the semester.

\section{Design}

Both quantitative and qualitative methods were used to answer the research questions, and to explore their attitudes and viewpoints about podcast-based vocabulary expansion. Pretest-posttest quasi-experimental design was used to examine the impact of podcasting on Iranian EFL learners' vocabulary learning. To triangulate the data, students' attitudes towards the effect of the program on their vocabulary learning were elicited using an 8-item Likert-type questionnaire. Moreover, their viewpoints about podcasting were elicited via semi-structured interviews with eight participants from the experimental group, up to the saturation point where the elicited data tended to become redundant. The interviews were transcribed and an inductive thematic analysis was utilized; the reported themes emerged from the data.

\section{Instrumentation}

In order to obtain the desired data, the data were collected through (1) a bio-data questionnaire (Appendix A), (2) a 20-item researcher-made vocabulary test (used as both a pre-test and post-test), (3) an 8-item Likert-type questionnaire (Appendix B) to elicit the participants' attitudes, with enough space for comments if they wished, and (4) oral interviews conducted to let them elaborate on their viewpoints about the impact of using podcasts. The second author conducted the interviews; participants were requested to choose to answer the questions either in English or Farsi (their L1). For the interviews, eight students (four students with higher vocabulary scores and four students with lower vocabulary scores) with varying vocabulary abilities from the experimental group participated in interviews, to cater for varying opinions. The interviews stopped at the point of data saturation.

\section{The procedure}

A 20-item vocabulary test was initially given to both control and experimental groups as a pretest, to determine their vocabulary scores as the starting point. The experimental group was instructed through listening to podcasts. In the control group, however, vocabulary was taught by routine instructional methods without podcasts, as practiced by the institute throughout years.

The classes met twice a week for 90 minutes, and the course continued for five weeks. In ten successive sessions, podcast-based materials were introduced and taught to participants in the experimental group. Most of the earlier studies used or recommended podcasts as supplementary learning tools because the learners practiced listening to podcasts at home besides attending classes (Lord, 2008; Evans, 2008). However, Shahid and Ali (2017) believed that the role of the teacher is vital in using podcasts in teaching.in the present study; therefore, the podcasts were played and intensively practiced in the classroom, mostly to make sure that participants had listened to materials at least once. Listening to each podcast took about 15 minutes each session, followed by vocabulary exercises practiced for about 10 minutes on average. Then they were encouraged to carefully listen to podcasts several times at home.

Meanwhile, the control group was taught by the ILI routine techniques of teaching vocabulary, which is mostly considered to be a modified version of audiolingual methodology with a considerable focus on grammar and drills for teaching dialogs with meager intensive work on vocabulary expansion.

After the course ended, the participants were given the vocabulary post-test and the Likert-type questionnaire; also, individual interviews were conducted to explore the experimental group participants' attitudes and viewpoints about the podcasting module.

\section{Results}

The participants were 60 male EFL learners whose bio-data (i.e. age, gender, and their past learning experiences) were collected through a questionnaire at the beginning of the semester. Their age ranged between 16 and 22 years old; none of the participants had the experience of podcast-based vocabulary expansion. They had all practiced vocabulary using traditional methods in previous classes. Below, we will present the results in two sections: quantitative and qualitative.

\section{The quantitative section}

To ascertain the normality of distribution of the data, one-sample Kolmogorov-Smirnov test was run. The $p$ values for the pretest scores of the control and experimental groups were .33 and .24 , respectively. Since the p-values were above .05 , a parametric test was used to analyze data (see appendix C).

The null hypothesis was that "using podcasts does not significantly affect students' vocabulary learning". In order to test this hypothesis, the independent samples t-test was run using SPSS 13 to see whether the experimental group outperformed the control group in the vocabulary pre-test. Table 3.1 below shows that the mean scores of the control and experimental groups (12.13 and 12.07, respectively) were not significantly different ( $p>0.05)$ (see Table 3.2 ). 
As shown in Table 3.2., the p value of .95 is greater than .05 , showing that the difference between the means is not statistically significant. In other words, the groups were homogeneous in terms of their vocabulary ability at the beginning of the study.

Table 1

The Mean Scores of Groups in the Pretest

\begin{tabular}{|llllll|}
\hline & Group & N & Mean & Std. Deviation & Std. Error Mean \\
\hline Pretest scores & Control & 30 & 12.1333 & 1.35782 & .24790 \\
& Group & & & & \\
& Experimental & 30 & 12.0667 & 1.36289 & .24883 \\
& Group & & & & \\
\hline
\end{tabular}

Table 2

T-value for the Vocabulary Performance of the Groups in the Pretest

\begin{tabular}{|c|c|c|c|c|c|c|c|c|c|c|}
\hline & & \multicolumn{2}{|c|}{$\begin{array}{l}\text { Levene's Test for Equality } \\
\text { of Variances }\end{array}$} & \multicolumn{7}{|c|}{ t-test for Equality of Means } \\
\hline & & \multirow[t]{2}{*}{$\mathrm{F}$} & \multirow[t]{2}{*}{ Sig. } & \multirow[t]{2}{*}{$\mathrm{t}$} & \multirow[t]{2}{*}{ DF } & \multirow[t]{2}{*}{$\begin{array}{l}\text { Sig. }(2- \\
\text { taied) }\end{array}$} & \multirow[t]{2}{*}{$\begin{array}{l}\text { Mean } \\
\text { Difference }\end{array}$} & \multirow[t]{2}{*}{$\begin{array}{l}\text { Std. Error } \\
\text { Difference }\end{array}$} & \multicolumn{2}{|c|}{$\begin{array}{l}95 \% \text { Confidence Interval of } \\
\text { the Difference }\end{array}$} \\
\hline & & & & & & & & & Lower & Upper \\
\hline $\begin{array}{l}\text { Pre- } \\
\text { test }\end{array}$ & $\begin{array}{l}\text { Equal variances } \\
\text { assumed }\end{array}$ & .004 & .953 & .190 & 58 & .850 & .06667 & .35124 & -.63642 & .76976 \\
\hline scores & $\begin{array}{l}\text { Equal variances not } \\
\text { assumed }\end{array}$ & & & .190 & 57.999 & .850 & .06667 & .35124 & -.63642 & .76976 \\
\hline
\end{tabular}

However, in the post-test, the independent samples t-test showed that the mean score of the experimental group (16.67) was greater than that of the control group (14.10) (Table 3.3). Also, Table 3.4 indicates that the p-value of .314 is much lower than .05, implying that the difference between the obtained means is statistically significant. Therefore, the null hypothesis which stated that "using podcast does not significantly affect students' vocabulary learning" is rejected. In other words, podcasts affected the participants' vocabulary learning.

Table 3

The Mean Scores of Groups in the Post-test

\begin{tabular}{|llllll|}
\hline & Group & N & Mean & Std. Deviation & Std. Error Mean \\
\hline Post-test scores & Control group & 30 & 14.1000 & 1.29588 & .23659 \\
\cline { 2 - 6 } & Experimental group & 30 & 16.6667 & .92227 & .16838 \\
\hline
\end{tabular}

Table 4

T-value for the Vocabulary of the Groups in the Posttest

\begin{tabular}{|c|c|c|c|c|c|c|c|c|c|c|}
\hline & & \multicolumn{2}{|c|}{$\begin{array}{l}\text { Levene's Test for Equality of } \\
\text { Variances }\end{array}$} & \multicolumn{7}{|c|}{ t-test for Equality of Means } \\
\hline & & \multirow[t]{3}{*}{$\mathrm{F}$} & \multirow[t]{3}{*}{ Sig. } & \multirow[t]{3}{*}{$\mathrm{t}$} & \multirow[t]{3}{*}{ DF } & \multirow{3}{*}{$\begin{array}{l}\text { Sig. }(2- \\
\text { taied })\end{array}$} & \multirow{3}{*}{$\begin{array}{l}\text { Mean } \\
\text { Difference }\end{array}$} & \multirow{3}{*}{$\begin{array}{l}\text { Std. Error } \\
\text { Difference }\end{array}$} & \multirow{2}{*}{\multicolumn{2}{|c|}{$\begin{array}{l}95 \% \\
\text { Confidence Interval } \\
\text { of the Difference }\end{array}$}} \\
\hline & & & & & & & & & & \\
\hline & & & & & & & & & Lower & Upper \\
\hline $\begin{array}{l}\text { Post- } \\
\text { test }\end{array}$ & $\begin{array}{l}\text { Equal variances } \\
\text { assumed }\end{array}$ & 1.033 & .314 & -8.839 & 58 & .000 & -2.56667 & .29040 & -3.14796 & -1.98538 \\
\hline scores & $\begin{array}{l}\text { Equal variances not } \\
\text { assumed }\end{array}$ & & & -8.839 & 52.379 & .000 & -2.56667 & .29040 & -3.14929 & -1.98405 \\
\hline
\end{tabular}

\section{The qualitative section}

\section{The Likert-type questionnaire}


The participants' attitudes towards podcast-based vocabulary expansion were elicited via a researcher-made 8-item questionnaire. When the instruction was over, 30 participants in the experimental group were given the questionnaire, and were asked to tick the Likert choices; they expressed their attitudes as follows: strongly agree, agree, no idea, disagree or strongly disagree. In addition to Likert-type statements, the questionnaire allowed some space for respondents to provide open-ended comments, if they wished to add any comments. They were also assured of the confidentiality of their views and personal information. The responses were entered into Excel for analysis and reporting the percentage. The analysis of the eight items are presented below one by one.

Item 1

\begin{tabular}{|llll|}
\hline & Strongly Agree and Agree & \multicolumn{2}{c|}{ Strongly Disagree and Disagree } \\
\hline Statement & \multicolumn{2}{c|}{ No idea } \\
\hline I often feel bored when listening to podcasts. & $6.67 \%$ & $26.67 \%$ & $66.67 \%$ \\
\hline
\end{tabular}

Comments: Three students commented that at first, listening to podcasts seemed to be tiresome but, gradually, they really enjoyed listening to them, especially when they discovered new spoken idioms and expressions in the content of podcasts. One of them commented, "I sometimes came up with expressions I was long looking for, it was just what I wanted in these years". Another participant commented, "Podcasts are interesting, because it discusses the most important subjects and gives information about different cultures". A student, however, commented that he felt bored because he could not focus on the content.

Item 2

\begin{tabular}{|c|c|c|c|}
\hline Statement & $\begin{array}{l}\text { Strongly Agree and } \\
\text { Agree }\end{array}$ & $\begin{array}{l}\text { No } \\
\text { idea }\end{array}$ & $\begin{array}{l}\text { Strongly Disagree and } \\
\text { Disagree }\end{array}$ \\
\hline $\begin{array}{l}\text { I like to learn English listening comprehension mainly through podcasts because listening } \\
\text { is very important. }\end{array}$ & $60.00 \%$ & $16.67 \%$ & $23.33 \%$ \\
\hline
\end{tabular}

Comments: There were two comments with regard to this question. One learner said that "Vocabulary is an important ability, but podcasting is only one way, I found other ways for improving my vocabulary." The other participant said, "My vocabulary isn't good. I like to be better, so I will listen to everything which helps me. And listening to podcasts is so cool."

Item 3

\begin{tabular}{|llll|}
\hline Statement & Strongly Agree and Agree & No idea & Strongly Disagree and Disagree \\
\hline I feel that I can learn through podcasts. & $86.67 \%$ & $6.67 \%$ & $6.67 \%$ \\
\hline
\end{tabular}

Comments: There was only one comment on this question. One participant said, "Speakers of this podcast file were so great. They were like classroom teachers. I sometimes feel they are in classroom teaching me. But I could not just ask them questions."

Item 4

\begin{tabular}{|llll|}
\hline Statement & Strongly Agree and Agree & No idea & Strongly Disagree and Disagree \\
\hline I would like teachers to use podcasts in my classes. & $70.00 \%$ & $16.67 \%$ & $13.33 \%$ \\
\hline
\end{tabular}

Comments: One student commented, "Podcasts are so funny and they teach me interesting and useful things. I thank you my teacher to use them in the classroom." Two other students believed that "podcasts are new and different from what they had already learned in previous classes".

Item 5

\begin{tabular}{|llll|}
\hline Statement & Strongly Agree and Agree & No idea & Strongly Disagree and Disagree \\
\hline I like listening to podcasts. & $70.00 \%$ & $16.67 \%$ & $13.33 \%$ \\
\hline
\end{tabular}

Comments: To this item, three students put their written comments. Two of them agreed with the idea that podcasts had motivated them to listen more. However, one student did not like the idea of listening to podcasts. He stated: "They are so boring, so I don't like listening to them. They are so easy, too. Honestly speaking, it was a waste of time for me." 


\section{Statement}

In order to improve my English vocabulary comprehension, I will spend much of my studying time listening to podcasts.

\section{Strongly Agree and \\ Agree}

$36.67 \%$
Strongly Disagree and Disagree

$46.67 \%$

Comments: Some students noted that there were other aspects of language which they needed to spend more time on. One student said he had little problem with vocabulary; therefore, he needed to spend most of his time practicing other skills. One student commented that the course was useful in integrating podcasts, and from then on, he had started listening more to podcasts to practice vocabulary in future.

Item 7

\begin{tabular}{|llll|}
\hline Statement & Strongly Agree and Agree & No idea & Strongly Disagree and Disagree \\
\hline I often feel nervous and uncomfortable when listening to podcasts. & $16.67 \%$ & $20.00 \%$ & $63.33 \%$ \\
\hline
\end{tabular}

Comments: Six students commented on this statement. While, one of them wrote: "I started well first, but after just two minutes I couldn't focus on the content. It's so hard to understand everything", some others believed that they had no or few problems when listening to podcasts.

Item 8

\begin{tabular}{|c|c|c|c|}
\hline Statement & $\begin{array}{l}\text { Strongly Agree and } \\
\text { Agree }\end{array}$ & $\begin{array}{l}\text { No } \\
\text { idea }\end{array}$ & $\begin{array}{l}\text { Strongly Disagree and } \\
\text { Disagree }\end{array}$ \\
\hline $\begin{array}{l}\text { I am sometimes unable to focus on and understand the content of the materials when } \\
\text { listening to podcasts. }\end{array}$ & $50.00 \%$ & $26.67 \%$ & $23.33 \%$ \\
\hline
\end{tabular}

Comments: There were six short comments on this statement. All of them implied that they sometimes had problems understanding the content of the materials.

\section{The verbal interview analysis}

To explore the participants' real perceptions of the impact of podcasting on Iranian EFL learners, four students with low vocabulary scores and four with high vocabulary scores were interviewed. The length of the interviews varied between five and ten minutes depending on the interviewees' willingness and eagerness to talk. The interviews were transcribed verbatim and analyzed thematically, by which the following themes emerged from the data: (1) vocabulary achievement, (2) learning by listening, (3) learner choice and flexibility, and (4) podcast as a useful instructional tool, which will be explained below.

\section{Theme one: Vocabulary achievement}

In the interviews, the students expressed their ideas about their improvement in vocabulary expansion. Unanimously, they reported higher gains in vocabulary scores. They also believed that they had been empowered in learning new vocabulary items more effectively and had developed sharp ears for spoken language; one said, "I am sure from now on I would have no problem listening to different listening materials if they are not much above my level, knowing the vocabulary and expressions."

Some of them stressed that they had gained more confidence in listening to longer stretches of speech such as stories or lectures. One student said, "The podcasting program helped me to willingly listen more by giving me more confidence and motivation in comprehending and by forcing me to do a lot of listening practice to improve my vocabulary." Although almost all participants felt that the podcasting experience helped them improve their vocabulary comprehension, they believed that they still needed more practice to achieve real proficiency.

\section{Theme two: Learning by listening}

Some interviewees believed that the process of 'learning by listening' was an advantage compared to reading textbooks. In this regard, one of them said, "To sit down and to read is very challenging; you have to be stuck in one place for a long time. But audio materials are not like that. It is easier to learn when we listen, especially when you understand everything." Another participant said, "I think it is the best way to improve our pronunciation. We can listen to words and we can check the pronunciation of all words, in this way, I can check or learn pronunciations of a lot of words because everything is so fast and I don't need to check them in my dictionary."

Another participant focused on the fact that listening to podcasts gives them an effortless and relaxed option to access ample information in general - all they had to do was to listen; he further added, "It was so great that how easy it was for me to access information on various topics, just listen to it and learn a lot of cultural notes and different hints on English usage. Actually no pain, all the gain!" As previously mentioned in section 3.1, none of participants had 
experience of using podcasts for learning. But they agreed that podcasting was such a new phenomenon for them. One of the interviewees pointed out that learning with podcasts represented a new and attractive experience, "That is a very fresh experience. In fact, I'd never heard of podcast before this class, I didn't even know what podcast was."

\section{Theme three: Learner choice and flexibility}

Many interviewees expressed that podcasts were flexible and convenient because the learners could listen to them at a convenient place, time and at a pace of their choice. The following comment reflects the potentiality of podcasts on different occasions, "It looked for me as if listening to music. Listening to music is my favorite hobby. I have a lot of small free times which I can't do anything else, so I used to listen to music. But now I can also like to listen to podcasts." A similar idea came from another participant, "I sometimes listened to podcasts when working with my computer." Similarly, a participant added, "I can listen to podcasts every time I like or I am free such as when I am on the bus or in the car and I can't do anything else. So, it is very good to learn English in such times. Because I have to learn English very soon."

\section{Theme four: Podcasts as useful instructional tools}

The last major theme emerging from the data was the participants' opinion about the auxiliary contribution of podcasts as instructional tools for extracurricular learning. One of them said, "Podcasting provides me an additional exposure to learn English. I think I need to practice more and more." Another learner added, "There is a lot to vocabulary and I should do a lot of listening to become better in vocabulary comprehension. With using podcasts I can practice vocabulary at home." Having experienced the podcasting project, the learners were aware of its advantages and disadvantages. As for the advantages of the program, one of the students commented that podcasts had made him somehow independent in terms of listening and vocabulary learning. Some of them found podcasting useful for speaking ability too, because they were able to pause after each sentence and repeat the same as a model. Interestingly, they preferred using new technology to traditional methods of vocabulary, since in this type of learning they can feel the presence of an amazing educational technology; one said, "I am tired of using my cell phone for just messaging and listening to music. Now, I have another application for it. I am happy to use it for my English learning".

However, some participants preferred to point to disadvantages too. Almost half of the interviewees said that some podcasts were lengthy and not interesting enough. Even one participant regarded 'making students listen to podcasts more than once' as a useless activity. One of the participants said, "they [podcasts] were so easy, so it was very boring job to listen to them more than once. I think they are useless when they are very easy". Another disadvantage they highlighted was the lack of pictures and videos to accompany the audio files. One learner rightly criticized that podcasts are just one-way learning objects with no interactional possibilities, and added, "we cannot interact with files, we must just listen to them, and when we have questions, we cannot ask them. But, when we listened to them in class that was no problem."

\section{Discussion}

The present study was conducted to investigate the impact of using podcasts as instructional tools on EFL learners' vocabulary learning, and to evaluate their attitude towards listening to podcasts. The results showed that 'listening to podcasts' improved the learners' vocabulary scores in the experimental group. Therefore, podcasts could be used in language classes, on the one hand, to help teachers and learners with improving auditory skills and vocabulary expansion (Mashhadi, Hayati \& Jalilifar, 2016), and on the other hand, to boost students' classroom motivation (Abdous, Camarena \& Facer, 2009; Asoodar, Marandi, Vaezi \& Desmet, 2016). In fact, the present study demonstrated the potential of podcasts to foster EFL learners' English vocabulary learning, which is in line with earlier studies (e.g. Stanley, 2006; Mashhadi, Hayati \& Jalilifar, 2016).

The results of the qualitative analysis showed that podcasts can be considered as supplementary instructional tools to improve the students' overall vocabulary scores. These findings are in line with earlier studies (e.g. Mashhadi, Hayati \& Jalilifar, 2016; Elekaei, Tabrizi \& Chalak, 2020), since the participants reflected positive perceptions due to the ease and convenience of using podcasts; or because they gained motivation to practice more listening materials (Asoodar, Marandi, Vaezi \& Desmet, 2016), which are really rich with new vocabulary items in context (Cambell, 2005; Evans, 2008); or because they encouraged 'active learning and listening' (Abdulrahman, Basalamah \& Widodo, 2018).

Also, in response to the Likert-type questionnaire, majority of the participants decided to continue to practice listening to podcasts in future. Based on this survey, $88 \%$ 'felt that they can learn through podcasts'. Furthermore, $70.59 \%$ liked the podcasting experience. To enrich the findings, semi-structured interviews were conducted and relevant themes appeared as (1) vocabulary achievement, (2) learning by listening, (3) learner choice and flexibility, and (4) podcast as useful instructional tools. Their positive attitudes and viewpoints are also in line with earlier studies (Rost, 2006; Cebeci \& Tekdal, 2006; Mashhadi, Hayati \& Jalilifar, 2016; Abdulrahman, Basalamah \& Widodo, 2018); they also found that podcasts can be used in educational settings in general and language teaching in particular to motivate students. Moreover, the point that podcasts can further motivate learners is frequently mentioned in the literature (e.g. Cambell, 2005; Evans, 2008; Asoodar, Marandi, Vaezi \& Desmet, 2016). However, our results contradict some earlier studies. For example, contrary to Cann (2007), the participants of the present study welcomed podcasts in their classes and stated that podcasts were beneficial learning tools for them, and they were enabled to learn through listening to podcasts. Another possibility of podcasts usage is for teachers to adopt them as means of communicating with students (Elekaei, Tabrizi \& Chalak, 2020).

\section{Conclusions}

Based on the results, 'listening to podcasts' can improve EFL learners' vocabulary scores; use of podcasts in language classes helps teachers with improving auditory skills and vocabulary instruction, and leads to higher vocabulary scores and positive attitudes. However, the retention of vocabulary gain is an aspect raised by researchers (e.g. Elekaei, Tabrizi \& Chalak, 2020) which requires special attention. Also, most EFL learners may start practicing with podcasting 
experience due to positive feelings, attitudes and viewpoints. This study bears implications for teaching and curriculum development in EFL contexts. First, podcasts should be given due attention because of their auditory advantages specifically learning vocabulary by listening practice. Second, EFL teachers are recommended to integrate podcasting exercises in their classes. Third, EFL learners might find a chance to practice becoming more responsible and autonomous in improving their vocabulary. However, the limitations or perceived disadvantages of podcasting for learners who do not feel at home with it should be re-considered before its integration into the course syllabus. Finally, a larger sample size in future studies, with a wider scope of gender and proficiency levels, may help clarify the points we have not been able to consider.

\section{Declarations}

\section{Acknowledgements}

We would like to express our gratitude to the participants who patiently cooperated in all stages of the study; also, special thanks goes to the Islamic Azad University of Golestan, Iran, where this research was approved and conducted.

\section{Authors' contributions}

The manuscript has been read and approved for publication by all authors. Authors' contributions are as follows: Conception and design: Behrooz Ghoorchaei, Nematullah Shomoossi and Hashem Rastegar; Acquisition, analysis and interpretation of data: Behrooz Ghoorchaei and Hashem Rastegar; Drafting the article: Nematullah Shomoossi, Behrooz Ghoorchaei and Mostafa Amiri; Revising it critically for important intellectual content: Nematullah Shomoossi, and Mostafa Amiri; Approved final version of the manuscript: Behrooz Ghoorchaei, Hashem Rastegar, Nematullah Shomoossi and Mostafa Amiri.

\section{Funding}

No funding was obtained for this research.

\section{Availability of data and materials}

The data and materials are available upon request.

\section{Competing interests}

The authors declare that there are no conflict of interests.

\section{References}

1. Abdous, M., Camarena, M. M., \& Facer, B. R. (2009). MALL technology: Use of academic podcasting in the foreign language classroom. ReCALL, 21(1), 7695. Retrieved from https://www.researchgate.net/publication/231894414

2. Abdulrahman, T., Basalamah, N., \& Widodo, M.R. (2018). The impact of podcasts in EFL students' listening comprehension. International Journal of language Education, 2(2): 23-33. https://doi: 10.26858/ijole.v2i2.5878

3. Asoodar, M., Marandi, S. S., Vaezi, S., \& Desmet, P. (2016). Podcasting in a virtual English for academic purposes course: Learner motivation. Interactive Learning Environments, 24(4), 875-896. https://doi:10.1080/10494820.2014.937344

4. Bamanger, E.M., \& Alhassan, R.A. (2015). Exploring Podcasting in English as a Foreign Language Learners' Writing Performance. Journal of Education and Practice, 6(11), 63-74. Retrieved from https://files.eric.ed.gov/fulltext/EJ1081725.pdf

5. Cambell, G. (2005). There's something in the air: podcasting in education. EDUCAUSE Review, 40(6), 32-47. Retrieved from http://macwww.cobw.com/MultiMedia\%20Articles/Podcasting\%20in\%20Education.pdf

6. Cann, A.J. (2007). Podcasting is Dead. Long Live Video! Bioscience Education e-Journal, 10(1), 1-4. https://doi:10.3108/beej.10.c1.

7. Cebeci, Z., \& Tekdal, M. (2006). Using Podcasts as Audio Learning Objects. Interdisciplinary Journal of Knowledge and Learning Objects, $2,47-57$. Retrieved from https://www.learntechlib.org/p/44813

8. Elekaei, A., Tabrizi, H.H., \& Chalak, A. (2020). Evaluating learners' vocabulary gain and retention in an e-learning context using vocabulary podcasting tasks: a case study. Turkish Online Journal of Distance Education-TOJDE21(2), 190-203. Retrieved from https://files.eric.ed.gov/fulltext/EJ1251086.pdf

9. Evans, C. (2008). The effectiveness of m-learning in the form of podcast revision lectures in higher education. Computers and Education, 50(2), 491-498. https://doi.org/10.1016/j.compedu.2007.09.016

10. Golonka, E.M., Bowles, A.R., Frank, V.M., Richardson, D. L., \& Freynik, S. (2014). Technologies for foreign language learning: A review of technology types and their effectiveness. Computer Assisted Language Learning, 27(1), 70-105. https://doi.org/10.1080/09588221.2012.700315

11. Kim, D., \& King, K. P. (2011). Implementing podcasts and blogs with ESOL teacher candidates' preparation: Interpretations and implications. International Forum of Teaching \& Studies, 7(2), 5-19. Retrieved from https://www.academia.edu/download/7646464/ifots-two-2011.pdf

12. Kurtz, B.L., Fenwick, J.B., \& Ellsworth, C.C. (2007). Using podcasts and tablet PCs in computer science. In Proceedings of the 45th Annual ACM Southeast Regional Conference, Winston-Salem, NC, USA. https://doi.org/10.1145/1233341.1233428.

13. Lord, G. (2008). Podcasting communities and second language pronunciation. Foreign Language Annals, 41(2), 364-379. https://doi.org/10.1111/j.19449720.2008.tb03297.x 
14. Madrid, D. (2002). The Power of the FL Teacher's Motivational Strategies. Retrieved from Cauce, 25, 369-422.

https://www.researchgate.net/profile/Daniel_Madrid/publication/28169562_The_power_of_the_FL_teacher's_motivational_strategies/links/54d9e6580cf2

15. Mashhadi, A., Hayati, M., \& Jalilifar, A. (2016). The Impact of Podcasts on English Vocabulary Development in a Blended Educational Model. Applied Research on English Language, 5(2), 145-172. https://doi: 10.22108/are.2016.20423

16. Min-Tun, C., \& Tzu-Ping, Y. (2010). Using video podcast to support language learning through YouTube: Strategies and challenges. E-Proceedings of the International Online Language Conference (IOLC), 54-59. Retrieved from https://scholar.google.com/scholar? cluster $=11433246539620710142 \& \mathrm{hl}=$ en\&as_sdt $=2005 \&$ sciodt $=0,5$

17. Read, B. (2007). How to podcast campus lectures. Chronicle of Higher Education, 53(21), Jan 26. Retrieved from https://www.itr8.com/attachments/chronicle_on_campus_podcasting.pdf

18. Rost, M. (2006). Listening in action: Activities for developing listening in language teaching. Englewood Cliffs, NJ: Prentice Hall.

19. Shahid, S. H., \& Ali, Z. (2017). Saudi EFL learners' attitude towards integration of video-podcasts in listening comprehension. European Journal of English Language Teaching, 2(2), 130-157. https://doi:10.5281/zenodo.891447

20. Shandle, D., \& Swanigan, M. (2005). Podcasting for dollars: Contextual analysis. Journal of Psychology, 25, 35-71.

21. Stanley, G. (2006). Podcasting: Audio on the Internet Comes of Age. TESL-EJ, 9(4), 1-7. Retrieved from https://tesl-ej.org/ej36/int.pdf

\section{Appendix}

\section{Appendix A: Bio-data Questionnaire}

Your teacher would be grateful if you kindly and attentively give the following personal information. The information will be kept confidential.

Name: Gender: Age:

1. Do you have any learning experiences in language institutes? If yes, how long?

2. Have you ever had any opportunity to visit or stay in an English speaking country? If yes, how long?

3. Have you ever passed any course on English writing? If yes, what are the courses? Explain how the instructor taught writing? How did they assess your writing ability?

4. Have you ever had any experience with writing portfolios? If yes, please explain what you did in the class? How did you like it?

\section{Appendix B: The Likert-type questionnaire}

\begin{tabular}{|c|c|c|c|c|c|c|}
\hline No & Statement & $\begin{array}{l}\text { Strongly } \\
\text { Agree }\end{array}$ & Agree & $\begin{array}{l}\text { No } \\
\text { idea }\end{array}$ & Disagree & $\begin{array}{l}\text { Strongly } \\
\text { Disagree }\end{array}$ \\
\hline 1 & I often feel bored when listening to podcasts. & & & & & \\
\hline 2 & $\begin{array}{l}\text { I like to learn English listening comprehension mainly through podcasts because listening is } \\
\text { very important. }\end{array}$ & & & & & \\
\hline 3 & I feel that I can learn through podcasts. & & & & & \\
\hline 4 & I would like teachers to use podcasts in my classes. & & & & & \\
\hline 5 & I like listening to podcasts. & & & & & \\
\hline 6 & $\begin{array}{l}\text { In order to improve my English vocabulary comprehension, I will spend much of my studying } \\
\text { time listening to podcasts. }\end{array}$ & & & & & \\
\hline 7 & I often feel nervous and uncomfortable when listening to podcasts. & & & & & \\
\hline 8 & $\begin{array}{l}\text { I am sometimes unable to focus on and understand the content of the materials when } \\
\text { listening to podcasts. }\end{array}$ & & & & & \\
\hline
\end{tabular}

\section{Appendix C. Results of Test of Normality}




\begin{tabular}{|llll|}
\hline \multicolumn{2}{|l|}{ One-Sample Kolmogorov-Smimov Test } & & \\
\hline $\mathrm{N}$ & & controlpre & exp.pre \\
\hline Normal Parameters ${ }^{\mathrm{a}}$ & Mean & 30 & 30 \\
\cline { 2 - 4 } & Std. Deviation & 1.35782 & 1.36289 \\
\hline Most Extreme Differences & Absolute & .172 & .186 \\
\cline { 2 - 4 } & Positive & .172 & .186 \\
\cline { 2 - 4 } & Negative & -.161 & -.147 \\
\hline Kolmogorov-Smirnov Z & & .945 & 1.020 \\
\hline Asymp. Sig. (2-tailed) & & .334 & .249 \\
\hline a. Test distribution is Normal. & & \\
\hline
\end{tabular}

